Supplementary Material for

\title{
Development of Group 6 Dearomatization Agents
}

\author{
Yunkyoung Ha ${ }^{\dagger}$ A. Stefan Dilsky, Peter M. Graham, Weijun Liu, Timothy M. Reichart, \\ Michal Sabat, Joseph M. Keane ${ }^{\ddagger}$ W. Dean Harman,
}

\section{Table of Contents:}

General Methods................................................................... 1

Synthesis and characterization of complexes 3 - 31...........S2

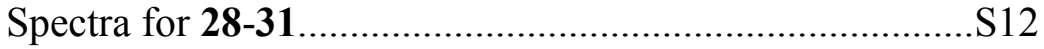

General Methods. NMR spectra were obtained on Varian (UnityInova 300 and 500, MercuryPlus 300) and Bruker (Avance 300, 400, and 500) spectrometers. Chemical shifts are reported in ppm and are referenced to tetramethylsilane (TMS) utilizing residual ${ }^{1} \mathrm{H}$ or ${ }^{13} \mathrm{C}$ signals of the deuterated solvents as internal standards. Chemical shifts are reported in ppm, and coupling constants $(J)$ are reported in hertz $(\mathrm{Hz})$. Resonances in the ${ }^{1} \mathrm{H}$ NMR spectra due to Tp pyrazolyl protons are listed by chemical shift and multiplicity only (all coupling constants are $2 \mathrm{~Hz}$ ). Infrared spectra (IR) were recorded on a Perkin Elmer spectrum BX II spectrometer as a concentrated solution between $\mathrm{NaCl}$ plates or on a MIDAC Prospect Series (Model PRS) spectrometer as either a glaze on a Horizontal Attenuated Total Reflectance (HATR) accessory (Pike Industries) or as a $\mathrm{KBr}$ pellet. Peaks are reported in $\mathrm{cm}^{-1}$, and solvents used in sample preparation are as indicated. Electrochemical experiments were performed under a nitrogen atmosphere using a BAS Epsilon EC-2000 or Cypress Systems model CySy 2Ra potentiostat. Cyclic voltammetric data were taken at ambient temperature at $100 \mathrm{mV} / \mathrm{s}$ in a standard three-electrode cell from +1.7 to $-1.7 \mathrm{~V}$ with a glassy-carbon working electrode, $N, N$-dimethylacetamide (DMA) solvent, and tetrabutylammonium hexafluorophosphate (TBAH) electrolyte $(\sim 0.5 \mathrm{M})$. All potentials are reported versus NHE (Normal Hydrogen Electrode) using cobaltocenium hexafluorophosphate $\left(E_{1 / 2}=\right.$ $0.78 \mathrm{~V})$ or ferrocene $\left(E_{1 / 2}=0.55 \mathrm{~V}\right)$ as an internal standard. The peak-to-peak separation was less than $100 \mathrm{mV}$ for all reversible couples. Mass spectra were obtained on a JEOL JMS600 spectrometer using $\mathrm{FAB}^{+}$or on a Finnagan MAT TSQ7000 spectrometer using $\mathrm{ESI}^{+}$. No counter ions were observed. Elemental analyses (EA) were performed on a Perkin-Elmer 2400 Series II CHNS/O Analyzer or on a CE Instruments Flash EA 1112 Series Elemental Analyzer or obtained from Atlantic Microlabs, Inc. X-ray data was 
collected on a Bruker SMART APEX CCD, Bruker SMART APEX II, or Siemens R3 Xray diffractometer. All synthetic reactions and electrochemical experiments were performed under a dry nitrogen atmosphere. Solvents were purchased as anhydrousgrade or purged with nitrogen and purified by passage through a column packed with activated alumina. Other liquid reagents were purged with nitrogen prior to use. Deuterated solvents were used as received from Cambridge Isotopes. Sodium amalgam ( $1.0 \%$ by weight), a viscous liquid, was prepared by adding small pieces of sodium to mercury slowly under an inert atmosphere. Zinc amalgam was prepared by reacting granular zinc (40 mesh) with a saturated aqueous solution of $\mathrm{HgCl}_{2}$. Compounds $\mathbf{1},{ }^{1}{ }^{2}{ }^{2}$ $\mathbf{1 1},{ }^{3} \mathbf{1 9},{ }^{4}$ and $\mathbf{2 1}{ }^{4}$ were previously reported.

[TpmMo(NO)Br $\left.\mathbf{T r}_{2}\right] \mathbf{B F}_{4}(\mathbf{3})$. To a suspension of $\left[\mathrm{TpmMo}(\mathrm{NO})(\mathrm{CO})_{2}\right] \mathrm{BF}_{4}(1.00 \mathrm{~g}, 2.07$ mmol) in 1,2-dichloroethane (30 mL) was added bromine (450 mg, $2.82 \mathrm{mmol})$ in 1,2dichloromethane $(5 \mathrm{~mL})$. The resulting mixture was refluxed for 3 hours. Gas evolution occured, and the yellow suspension turned brown. The reaction mixture was cooled to room temperature, filtered through celite $(\sim 1 \mathrm{~cm})$ on a coarse frit, and washed with small amounts of dichloromethane until the washings remained colorless. The solvent of the red-brown solution was reduced to $\sim 10 \mathrm{~mL}$, and diethyl ether $(50 \mathrm{~mL})$ was added. The precipitate was filtered off, washed with ether $(2 \times 15 \mathrm{~mL})$, and vacuum dried to give 3 (945- $985 \mathrm{mg}, 1.61-1.68 \mathrm{mmol}, 78-81 \%)$ as an orange-red powder. ${ }^{1} \mathrm{H} \mathrm{NMR}\left(\mathrm{CDCl}_{3}\right.$ and $\left.\mathrm{CD}_{3} \mathrm{CN}, 2: 1 \mathrm{v}: \mathrm{v}, \delta\right): 9.93\left(\mathrm{~s}, 1 \mathrm{H}, \mathrm{HC}(\mathrm{pz})_{3}\right), 8.61(\mathrm{br} \mathrm{s}, 2 \mathrm{H}), 8.46(\mathrm{~d}, J=2.4,1 \mathrm{H}), 8.07$ $(\mathrm{d}, J=2.4,1 \mathrm{H}), 7.99$ (br s, $2 \mathrm{H}), 6.58($ br s, $1 \mathrm{H}), 6.55(\mathrm{t}, J=2.4,2 \mathrm{H}) .{ }^{13} \mathrm{C} \mathrm{NMR}\left(\mathrm{CDCl}_{3}\right.$ and $\left.\mathrm{CD}_{3} \mathrm{CN}, 2: 1 \mathrm{v}: \mathrm{v}, \delta\right): 147.4,147.0,135.1,134.6,110.1,108.7,74.7\left(\mathrm{HC}(\mathrm{pz})_{3}\right)$. IR (HATR, $\mathrm{CH}_{2} \mathrm{Cl}_{2,} \mathrm{~cm}^{-1}$ ): 1731 (NO). Anal. calcd for $\mathrm{C}_{10} \mathrm{H}_{10} \mathrm{BBr}_{2} \mathrm{~F}_{4} \mathrm{MoN}_{7} \mathrm{O}: \mathrm{C}, 20.47 ; \mathrm{H}$, $1.72 ; \mathrm{N}, 16.71$. Found: C, 20.13; H, 1.75; N, 16.13.

$\left[\mathbf{T p m W}(\mathbf{N O}) \mathrm{Br}_{2}\right] \mathrm{BF}_{4}(4)$. To a suspension of $\left[\mathrm{TpmW}(\mathrm{NO})(\mathrm{CO})_{2}\right] \mathrm{BF}_{4}(1.50 \mathrm{~g}$, $2.63 \mathrm{mmol})$ in 1,2-dichloroethane $(30 \mathrm{~mL})$ was added bromine $(420 \mathrm{mg}, 2.63 \mathrm{mmol})$ in 1,2-dichloromethane $(5 \mathrm{~mL})$. The resulting mixture was refluxed for 1 hour. Gas evolution occurred, and the color of the suspension changed from orange to brown. The reaction mixture was cooled to ambient temperature, ether $(30 \mathrm{~mL})$ was added, and the resulting mixture was stirred for an additional hour. The precipitate was collected by filtration, washed with ether $(2 \times 15 \mathrm{~mL})$, and vacuum dried to give $4(1.51-1.60 \mathrm{mg}$, 2.24 - $2.37 \mathrm{mmol}, 85-90 \%)$ as a dark yellow powder. ${ }^{1} \mathrm{H} \mathrm{NMR}\left(\mathrm{CD}_{3} \mathrm{CN}, \delta\right): 9.50(\mathrm{~s}, 1 \mathrm{H}$, $\left.\mathrm{HC}(\mathrm{pz})_{3}\right), 8.62(\mathrm{~d}, J=2.4,2 \mathrm{H}), 8.54(\mathrm{~d}, J=2.4,1 \mathrm{H}), 8.46(\mathrm{~d}, J=2.4,1 \mathrm{H}), 8.33(\mathrm{~d}, J=$ $2.4,2 \mathrm{H}), 6.76(\mathrm{t}, J=2.4,1 \mathrm{H}), 6.72(\mathrm{t}, J=2.4,2 \mathrm{H}) .{ }^{13} \mathrm{C} \mathrm{NMR}\left(\mathrm{CD}_{3} \mathrm{CN}, \delta\right): 149.4,149.1$, 137.5, 136.9, 111.7, 110.3, 77.0 (HC(pz) $)$. IR (HATR, acetone, $\left.\mathrm{cm}^{-1}\right): 1638 \mathrm{~cm}^{-1}(\mathrm{NO})$. IR (HATR, $\mathrm{CH}_{3} \mathrm{CN}, \mathrm{cm}^{-1}$ ): $1692(\mathrm{NO}), 1651$ (sh, NO). Anal. calcd for $\mathrm{C}_{10} \mathrm{H}_{10} \mathrm{BBr}_{2} \mathrm{~F}_{4} \mathrm{~N}_{7} \mathrm{OW}$ : C, 17.80; $\mathrm{H}, 1.49 ; \mathrm{N}, 14.53$. Found: $\mathrm{C}, 17.17 ; \mathrm{H}, 1.47 ; \mathrm{N}, 14.24$.

TpMeImW(NO)Br (5). To TpW(NO)Br 2 (1.025 g, $1.747 \mathrm{mmol})$ in benzene (12 $\mathrm{mL}$ ) was added excess zinc dust $(500 \mathrm{mg})$ and 1 -methylmaleimide $(292.0 \mathrm{mg})$. The resulting heterogeneous mixture was stirred for 45 minutes. Spectral data was collected on the resulting unpurified material. IR $\left(\mathrm{HATR}, \mathrm{cm}^{-1}\right): 1563(\mathrm{NO}) . \mathrm{CV}: E_{1 / 2}=-1.55 \mathrm{~V}$, $E_{\mathrm{p}, \mathrm{a}}=+0.14 \mathrm{~V}$.

TpW(NO)(DMAP)(Br) (6): To TpW(NO)Br 2 (3.17 g, 5.40 mmol) was added excess zinc dust ( $3 \mathrm{~g}$ ) and a solution $N, N$-dimethyl-4-aminopyridine (DMAP, $1.36 \mathrm{~g}$ ) dissolved in THF $(30 \mathrm{~mL})$. The resulting mixture was stirred overnight. The insoluble portion of the reaction mixture was collected on a medium porosity frit. The crude mixture was 
dissolved in $\mathrm{CH}_{2} \mathrm{Cl}_{2}$ and chromatographed on silica $(3 \mathrm{~cm})$. Elution with THF gave a brown fraction that was discarded. Elution with acetone gave a yellow fraction that was discarded. Elution with methanol gave a brown fraction. The solvent of this brown fraction was removed under reduced pressure, and the resulting residue was dissolved in ethanol $(10 \mathrm{~mL})$ and added to pentane $(100 \mathrm{~mL})$. The resulting precipitate was collected on a medium-porosity frit and dried in vacuo to give $\mathbf{6}(23.6 \mathrm{mg}, 0.395 \mathrm{mmol}, 0.7 \%)$ as a yellow powder. IR $\left(\mathrm{HATR}, \mathrm{cm}^{-1}\right): 1567(\mathrm{NO}) . \mathrm{CV}: E_{1 / 2}=-1.36 \mathrm{~V}, E_{\mathrm{p}, \mathrm{a}}=+0.16 \mathrm{~V}$. MS (FAB): $\mathrm{M}^{+}=628$.

Tp(pyridine)W(NO)Br (7). To TpW(NO)Br $r_{2}(2.36 \mathrm{~g}, 4.016 \mathrm{mmol})$ in benzene $(13 \mathrm{~mL})$ was added excess zinc dust $(1 \mathrm{~g})$ and pyridine $(6 \mathrm{~mL})$. The resulting hetereogeneous mixture was stirred for 5 minutes, during which time it turned dark red. Solids were removed using a medium-porosity frit, and the filtrate was chromatographed on silica $(5 \mathrm{~cm})$ using ether as the eluent. A red fraction $\left(\sim 125 \mathrm{~mL}, v_{\mathrm{NO}}=1572 \mathrm{~cm}^{-1}\right)$ was collected, and its solvent was evaporated under reduced pressure. The resulting residue was dissolved in $\mathrm{CH}_{2} \mathrm{Cl}_{2}(5 \mathrm{~mL})$ and added to pentane $(100 \mathrm{~mL})$. The resulting red precipitate was collected on a medium-porosity frit and dried in vacuo to give 7 (857.1 $\mathrm{mg}, 1.462 \mathrm{mmol}, 36 \%)$ as a red powder. IR $\left(\mathrm{HATR}, \mathrm{cm}^{-1}\right): 1572(\mathrm{NO}) . \mathrm{CV}: E_{1 / 2}=-$ $1.31 \mathrm{~V}, E_{\mathrm{p}, \mathrm{a}}=+0.25 \mathrm{~V}$. MS $(\mathrm{FAB}): \mathrm{M}^{+}=586$.

Tp(nicotine)W(NO)Br (8). To TpW(NO)Br 2 (807.3 mg, $1.376 \mathrm{mmol})$ in $\mathrm{CH}_{2} \mathrm{Cl}_{2}$ $(2 \mathrm{~mL})$ was added excess zinc dust $(600 \mathrm{mg})$ and excess nicotine $(2 \mathrm{~mL})$. The resulting heterogeneous reaction mixture was stirred for 5 minutes, during which time it became dark red. The reaction mixture was chromatographed on silica $(3 \mathrm{~cm})$, using $\mathrm{CH}_{2} \mathrm{Cl}_{2}$ as the eluent. The solvent of the purple $\mathrm{CH}_{2} \mathrm{Cl}_{2}$ fraction was removed under reduced pressure, and the resulting residue was then dissolved in $\mathrm{CH}_{2} \mathrm{Cl}_{2}(6 \mathrm{~mL})$ and added to pentane $(75 \mathrm{~mL})$. The resulting precipitate was collected on a medium-porosity frit and dried in vacuo to give $8(88.7 \mathrm{mg}, 0.133 \mathrm{mmol}, 10 \%)$ as a red powder. IR (HATR, $\mathrm{cm}^{-1}$ ): $1576(\mathrm{NO}) . \mathrm{CV}: E_{1 / 2}=-1.35 \mathrm{~V}, E_{\mathrm{p}, \mathrm{a}}=+0.21 \mathrm{~V}$.

Tp(SMe $)$ W(NO)Br (9). To TpW(NO)Br 2 (1.05 g, $1.787 \mathrm{mmol})$ in $\mathrm{CH}_{2} \mathrm{Cl}_{2}(10$ $\mathrm{mL}$ ) was added excess zinc dust $(600 \mathrm{mg})$ and excess dimethylsulfide $(1 \mathrm{~mL})$. The resulting heterogeneous reaction mixture was vigorously stirred for 2.5 hours. The reaction mixture was then chromatographed on silica $(3 \mathrm{~cm})$, first using benzene:diethyl ether $(2: 1 \mathrm{v}: \mathrm{v})$ as the eluent. A yellow fraction was collected and discarded. By eluting with 1:2 benzene:diethyl ether, a green fraction was collected. The solvent of this fraction was evaporated under reduced pressure until the remaining solution froze. The volume of solvent was doubled with pentane, and the resulting precipitate was collected on a medium-porosity frit and dried in vacuo to give $9(403.8 \mathrm{mg}, 0.710 \mathrm{mmol}, 40 \%)$ as a yellow-green powder. IR $\left(\mathrm{HATR}, \mathrm{cm}^{-1}\right): 1576(\mathrm{NO}) . \mathrm{CV}: E_{1 / 2}=-1.37 \mathrm{~V}, E_{\mathrm{p}, \mathrm{a}}=+0.37 \mathrm{~V}$.

Tp(t-BuMeS)W(NO)Br (10). To TpW(NO)Br $\left.\mathrm{Br}_{2}, 759.7 \mathrm{mg}, 1.295 \mathrm{mmol}\right)$ in $\mathrm{CH}_{2} \mathrm{Cl}_{2}(4 \mathrm{~mL})$ was added excess zinc dust $(1 \mathrm{~g})$ and excess tert-butyl methyl sulfide (1 $\mathrm{mL}$ ). The resulting heterogeneous mixture was stirred vigorously for 2 hours. It was then chromatographed on silica $(3 \mathrm{~cm})$ using $\mathrm{CH}_{2} \mathrm{Cl}_{2}$ as the eluent. An orange fraction was collected and discarded. A green fraction was collected, and its solvent volume was evaporated to $10 \mathrm{~mL}$ under reduced pressure. Upon addition of pentane $(50 \mathrm{~mL})$, a precipitate formed. It was collected on a medium-porosity frit and dried in vacuo to give $10(71.8 \mathrm{mg}, 0.1175 \mathrm{mmol}, 9 \%)$ as a green powder. IR (HATR, $\left.\mathrm{cm}^{-1}\right)$ : 1577 (NO). CV: $E_{\mathrm{p}, \mathrm{c}}=-1.38 \mathrm{~V}, E_{\mathrm{p}, \mathrm{a}}=+0.33 \mathrm{~V}$. 
Tp(PEt $\left.{ }_{3}\right) \mathbf{W}(\mathbf{N O})(\mathbf{B r})$ (12). To TpW(NO)Br ${ }_{2}(15.3 \mathrm{~g}, 26.08 \mathrm{mmol})$ in $\mathrm{CH}_{2} \mathrm{Cl}_{2}$ $(700 \mathrm{~mL})$ was added triethylphosphine $(5.9 \mathrm{~g}, 50 \mathrm{mmol})$ and excess zinc amalgam $(9.1$ g). The resulting mixture was stirred for 5 minutes and monitored by IR. It was chromatographed on silica $(6 \mathrm{~cm})$ using $\mathrm{CH}_{2} \mathrm{Cl}_{2}$ as the eluent. A green fraction $(\sim 600$ $\mathrm{mL}$ ) was collected and its volume was reduced by evaporation to $100 \mathrm{~mL}$. Hexanes $(250$ $\mathrm{mL}$ ) was added to produce a green precipitate which was collected on a medium-porosity frit and dried in vacuo to give $\mathbf{1 2}(9.57 \mathrm{~g}, 15.24 \mathrm{mmol}, 58 \%)$ as a green powder. IR $\left(\mathrm{HATR}, \mathrm{cm}^{-1}\right): 1578(\mathrm{NO})$. CV: $E_{1 / 2}=-1.40 \mathrm{~V}, E_{\mathrm{p}, \mathrm{a}}=+0.32 \mathrm{~V}$.

Tp(THT)W(NO)(Br) (13). To TpW(NO)Br ${ }_{2}(1.15 \mathrm{~g}, 1.957 \mathrm{mmol})$ in $\mathrm{CH}_{2} \mathrm{Cl}_{2}(8$ $\mathrm{mL}$ ) was added excess zinc dust $(1 \mathrm{~g})$ and excess tetrahydrothiophene (THT, $1 \mathrm{~mL})$. The resulting heterogeneous mixture was stirred vigorously for 1 hour. The reaction mixture was chromatographed on silica $(3 \mathrm{~cm})$ using diethyl ether as the eluent. A green fraction $(50 \mathrm{~mL})$ was collected, and its volume was doubled with pentane. Resulting precipitate was collected on a medium-porosity frit and dried in vacuo to give $\mathbf{1 3}(170.4 \mathrm{mg}, 0.2864$ mmol, $15 \%)$ as a green powder. IR $\left(\operatorname{HATR~cm}^{-1}\right): 1578(\mathrm{NO})$. CV: $E_{1 / 2}=-1.33 \mathrm{~V}, E_{\mathrm{p}, \mathrm{a}}=$ $+0.32 \mathrm{~V}$.

Tp(DMN)W(NO)Br (14). To TpW(NO) $\mathrm{Br}_{2}\left(972.8 \mathrm{mg}, 1.658 \mathrm{mmol}\right.$ ) in $\mathrm{CH}_{2} \mathrm{Cl}_{2}$ $(2 \mathrm{~mL}$ ) was added excess zinc dust $(600 \mathrm{mg}$ ) and $N, N$-dimethylnicotinamide (DMN, 1.09 g). The resulting heterogeneous mixture was stirred for 10 minutes, during which time it became dark red. Solids were removed by filtration through a medium-porosity frit, and the filtrate was chromatographed on silica $(3 \mathrm{~cm})$ using $\mathrm{CH}_{2} \mathrm{Cl}_{2}$ as the eluent. The solvent of the $\mathrm{CH}_{2} \mathrm{Cl}_{2}$ fraction was removed under reduced pressure, and the resulting residue was dissolved in $\mathrm{CH}_{2} \mathrm{Cl}_{2}(6 \mathrm{~mL})$ and added to pentane $(75 \mathrm{~mL})$. The resulting red precipitate was collected on a medium-porosity frit, washed with ether $(100 \mathrm{~mL})$, and dried in vacuo to give $\mathbf{1 4}(206.4 \mathrm{mg}, 0.314 \mathrm{mmol}, 19 \%)$ as a red-brown powder. IR $\left(\mathrm{HATR}, \mathrm{cm}^{-1}\right): 1578(\mathrm{NO}) . \mathrm{CV}: E_{1 / 2}=-1.20 \mathrm{~V}, E_{\mathrm{p}, \mathrm{a}}=+0.28 \mathrm{~V}$.

$\mathbf{T p}\left(\mathbf{P H}_{2} \mathbf{C y}\right) \mathbf{W}(\mathbf{N O})(\mathbf{B r})$ (15). To TpW(NO) $\mathrm{Br}_{2}(770.0 \mathrm{mg}, 1.312 \mathrm{mmol})$ in $\mathrm{CH}_{2} \mathrm{Cl}_{2}(50 \mathrm{~mL})$ was added a solution of cyclohexylphosphine $\left(\mathrm{PH}_{2} \mathrm{Cy}, 3.2 \mathrm{~g}, 10 \%\right.$ by weight in hexanes, $2.9 \mathrm{mmol}$ ) and excess zinc amalgam $(4 \mathrm{~g})$. The resulting mixture was stirred for 10 minutes with IR monitoring. The mixture was chromatographed on silica $(3 \mathrm{~cm})$, using $\mathrm{CH}_{2} \mathrm{Cl}_{2}$ as the eluent. A green fraction $(\sim 100 \mathrm{~mL})$ was collected and reduced by evaporation to a volume of $10 \mathrm{~mL}$. To this solution, hexanes $(50 \mathrm{~mL})$ was added to produce a green precipitate. This was collected on a medium-porosity frit and dried in vacuo to give 15 (421 $\mathrm{mg}, 0.683 \mathrm{mmol}, 52 \%)$ as a green powder. IR (HATR, $\left.\mathrm{cm}^{-1}\right): 1587(\mathrm{NO})$. CV: $E_{1 / 2}-1.24 \mathrm{~V}, E_{\mathrm{p}, \mathrm{a}}=+0.39 \mathrm{~V}$.

$\mathbf{T p}\left(\mathbf{P}(\mathbf{O M e})_{3}\right) \mathbf{W}(\mathbf{N O}) \mathbf{B r}(\mathbf{1 6})$. $\mathrm{P}(\mathrm{OMe})_{3}(7.4 \mathrm{~g}, 60 \mathrm{mmol}, 7 \mathrm{eq})$ was added to $\mathrm{TpW}(\mathrm{NO}) \mathrm{Br}_{2}(4.992 \mathrm{~g}, 8.509 \mathrm{mmol})$ in $\mathrm{CH}_{2} \mathrm{Cl}_{2}(450 \mathrm{~mL})$ and stirred. Excess zinc amalgam $(5.2 \mathrm{~g})$ was added, and the reaction was stirred for 2.5 hours and monitored by IR. The reaction mixture was chromatographed on silica $(5 \mathrm{~cm})$ using $\mathrm{CH}_{2} \mathrm{Cl}_{2}$ as the eluent. A dark green fraction was collected $(\sim 500 \mathrm{~mL})$ with $v_{\mathrm{NO}}=1597 \mathrm{~cm}^{-1}$. The solvent of the green fraction was reduced by half, and hexanes $(250 \mathrm{~mL})$ was added to produce a green precipitate which was collected on a medium-porosity frit and dried in vacuo to give 16 ( $4.166 \mathrm{~g}, 6.615 \mathrm{mmol}, 78 \%$ yield) as a green powder. IR (HATR, $\mathrm{cm}^{-}$ $\left.{ }^{1}\right): 1597(\mathrm{NO}) . \mathrm{CV}: E_{1 / 2}=-1.04 \mathrm{~V}, E_{\mathrm{p}, \mathrm{a}}=+0.51 \mathrm{~V} . \mathrm{MS}(\mathrm{FAB}): \mathrm{M}^{+}=630$.

Tp(t-BuNC)W(NO)Br (17). To TpW(NO)Br ${ }_{2}(1.23 \mathrm{~g}, 2.091 \mathrm{mmol})$ in benzene $(20 \mathrm{~mL})$ was added excess zinc dust $(1 \mathrm{~g})$, and a solution of tert-butyl isonitrile $(240 \mathrm{mg})$ 
in THF ( $2 \mathrm{~mL})$. The resulting heterogeneous mixture was stirred for 30 minutes. It was then chromatographed on silica $(3 \mathrm{~cm})$, using benzene/ether $(1: 1 \mathrm{v}: \mathrm{v})$ as the eluent. A yellow-green fraction was collected, and its solvent was evaporated to $10 \mathrm{~mL}$ under reduced pressure. It was to pentane $(50 \mathrm{~mL})$, and the resulting precipitate was collected on a medium-porosity frit and dried in vacuo to give 17 (375.1 $\mathrm{mg}, 0.6359 \mathrm{mmol}, 30 \%)$ as a yellow-green powder. IR $\left(\mathrm{HATR}, \mathrm{cm}^{-1}\right): 1600(\mathrm{NO}), 2154(\mathrm{CN}) . \mathrm{CV}: E_{1 / 2}=-0.71$ $\mathrm{V}, E_{\mathrm{p}, \mathrm{a}}=+0.41 \mathrm{~V}$. MS (FAB): $\mathrm{M}^{+}=589$.

$\left[\mathbf{T p m}\left(\mathbf{P}(\mathbf{O M e})_{3}\right) \mathbf{W}(\mathbf{N O}) \mathbf{B r}\right) \mathbf{B F}_{4}(\mathbf{1 8})$. To a mixture of THF $(20 \mathrm{~mL})$ and $\mathrm{CH}_{2} \mathrm{Cl}_{2}$ $(5 \mathrm{~mL})$ was added [TpmW(NO)Br $\left.\mathrm{Br}_{2}\right] \mathrm{BF}_{4}(1.50 \mathrm{~g}, 2.22 \mathrm{mmol})$ and zinc dust $(500 \mathrm{mg}, 7.65$ $\mathrm{mmol})$. The resulting heterogenous mixture is stirred vigorously, and trimethylphosphite $(1.50 \mathrm{~mL}, \sim 1,58 \mathrm{~g}, \sim 12.7 \mathrm{mmol})$ was added. The reaction was monitored by IR, and after several days the dark suspension was filtered through celite on a coarse frit, and the celite was washed with THF until the washings remained colorless $(\sim 100 \mathrm{~mL})$. The volume of the brown filtrate solution was evaporated under vacuum to $\sim 5 \mathrm{~mL}$, and addition of ether $(80 \mathrm{~mL})$ produced a precipitate. It was collected by filtration, washed with $\mathrm{Et}_{2} \mathrm{O}$, and vacuum dried to give 18 (600 - $620 \mathrm{mg}, 0.835$ - $0.862 \mathrm{mmol}, 37$ - 39\%) as a yellowbrown powder. IR (HATR, THF, $\left.\mathrm{cm}^{-1}\right)$ : $1619(\mathrm{NO}) . \mathrm{CV}: E_{1 / 2}=-0.67 \mathrm{~V}$. Anal. calcd for $\mathrm{C}_{13} \mathrm{H}_{19} \mathrm{BBrF}_{4} \mathrm{~N}_{7} \mathrm{O}_{4} \mathrm{PW}$ : C, 21.72; H, 2.66; N, 13.64. Found: C, 21.59; H, 2.70; N, 13.13.

Tp(Pic)Mo(NO)Br (20). To a $250 \mathrm{~mL}$ round-bottom flask was added $\mathrm{TpMo}(\mathrm{NO}) \mathrm{Br}_{2}(2.060 \mathrm{~g}, 4.13 \mathrm{mmol})$, zinc dust $(.542 \mathrm{~g}, 8.29 \mathrm{mmol})$, and THF $(200 \mathrm{~mL})$. The resulting mixture was stirred vigorously for 10 minutes during which time the solution changed color from red to dark green. 4-picoline $(0.379 \mathrm{~g}, 4.67 \mathrm{mmol})$ was added, and the mixture was stirred for an additional 10 minutes, over which time the solution turned to a brighter green. The solution was decanted through a silica plug on a $150 \mathrm{~mL}$ medium-porosity fritted glass disk, and the plug was washed with THF. The combined eluent was evaporated to $25 \mathrm{~mL}$, and pentane $(100 \mathrm{~mL})$ was added to precipitate a $20(89 \%)$ as a green solid. IR (HATR, $\left.\mathrm{cm}^{-1}\right): 2494(\mathrm{BH}), 1605$ (NO). CV: $E_{1 / 2}=-1.42 \mathrm{~V}, E_{\mathrm{p}, \mathrm{a}}=+0.50 \mathrm{~V}$.

Tp(DMAP)Mo(NO)Br (22). To a $250 \mathrm{~mL}$ round-bottom flask was added TpMo(NO)Br 2 (2.050g, $4.110 \mathrm{mmol})$, zinc dust (1.498 g, $22.91 \mathrm{mmol})$, and THF (200 $\mathrm{mL}$ ). The mixture was stirred vigorously, and over the course of 10 minutes it changed from red to dark green. 4-Dimethylaminopyridine (DMAP, 0.600g, $4.91 \mathrm{mmol}$ ) was added, and the mixture was stirred for an additional 10 minutes, during which time it turned a brighter green. The solution was decanted through a silica plug in a $150 \mathrm{~mL}$ medium-fritted Büchner funnel and washed with THF. The eluent was reduced to $25 \mathrm{~mL}$, and pentane $(100 \mathrm{~mL})$ was added to precipitate $22(3.27 \mathrm{~g}, 61 \%)$ as a green solid. IR $\left(\mathrm{HATR}, \mathrm{cm}^{-1}\right): 2511(\mathrm{BH}), 1613(\mathrm{NO}) . \mathrm{CV}: E_{1 / 2}=-1.53 \mathrm{~V}, E_{\mathrm{p}, \mathrm{a}}=+0.64 \mathrm{~V}$. Tp(PMe $\left.\mathbf{P}_{3}\right) \mathbf{M o}(\mathbf{N O}) B r(\mathbf{2 3})$. To a $250 \mathrm{~mL}$ round-bottom flask was added TpMo(NO)Br 2 (1.855 g, $3.719 \mathrm{mmol})$, zinc dust $(0.455 \mathrm{~g}, 6.96 \mathrm{mmol})$, and THF (200 $\mathrm{mL})$. The mixture was stirred vigorously for 10 minutes, during which time the solution changed color from red to dark green. Trimethylphosphine $(0.315 \mathrm{~g}, 4.14 \mathrm{mmol})$ was added and the solution was stirred for an additional 10 minutes, during which time the solution turned to a brighter green. The solution was decanted through a silica plug in a $150 \mathrm{~mL}$ medium-porosity fritted Büchner funnel, and the plug was washed with THF. The combined eluent was evaporated to a volume to $25 \mathrm{~mL}$, and pentane $(100 \mathrm{~mL})$ was 
added to precipitate $23(76 \%)$ as a green solid. IR (HATR, $\left.\mathrm{cm}^{-1}\right): 2490(\mathrm{BH}), 1617$ (NO). CV: $E_{1 / 2}=-1.19 \mathrm{~V}$.

Tp(t-BuNC)Mo(NO)Br (24). To a $250 \mathrm{~mL}$ round-bottom flask was added TpMo(NO)Br 2 (3.090g, $6.195 \mathrm{mmol}$ ), zinc dust (1.208g, $18.47 \mathrm{mmol}$ ), and (THF) 200 $\mathrm{mL}$. The resulting mixture was stirred vigorously for 10 minutes, during which time the solution changed color from red to dark green. Tert-butylisonitrile $(0.552 \mathrm{~g}, 6.639 \mathrm{mmol})$ was added, and the solution was stirred for an additional 10 minutes, during which time the solution turned to a brighter green. The solution was decanted through a silica plug on a $150 \mathrm{~mL}$ medium-porosity fritted glass disk and the plug was washed with THF. The combined eluent was reduced to $25 \mathrm{~mL}$, and pentane $(100 \mathrm{~mL})$ was added to precipitate $24(45 \%)$ as a green solid. IR (HATR, $\left.\mathrm{cm}^{-1}\right): 2512(\mathrm{BH}), 1618(\mathrm{NO}) . \mathrm{CV}: E_{1 / 2}=-1.23$ $\mathrm{V}, E_{\mathrm{p}, \mathrm{a}}=0.76 \mathrm{~V}$.

[Tpm(MeIm)Mo(NO)Br]BF 4 (25). To a vigorously stirred suspension of

[TpmMo(NO)Br ${ }_{2} \mathrm{BF}_{4}(350 \mathrm{mg}, 0.596 \mathrm{mmol})$ and zinc dust (150 mg, $\left.2.29 \mathrm{mmol}\right)$ in $\mathrm{CH}_{2} \mathrm{Cl}_{2}(5 \mathrm{~mL})$ was added a solution of 1-methylimidazole (MeIm, $250 \mathrm{mg}, \sim 240 \mu \mathrm{L}$, $3.04 \mathrm{mmol})$ in THF $(5 \mathrm{~mL})$. The dark red reaction mixture turned green. After 2 hours, the reaction mixture was filtered through celite on a coarse frit and the celite was washed with $\mathrm{CH}_{2} \mathrm{Cl}_{2}(\sim 40 \mathrm{~mL})$ until the washings remained colorless, leaving behind a small amount of green material on top of the celite. The volume of the dark green filtrate solution was reduced to $\sim 3 \mathrm{~mL}$ under vacuum, and ether was used to give a precipitate. This was collected by filtration, washed with ether, and dried under vacuum to give $\mathbf{2 5}$ (258 mg, $0.438 \mathrm{mmol}, 73 \%$ ) as a bright green powder. IR (HATR, $\mathrm{CH}_{2} \mathrm{Cl}_{2}, \mathrm{~cm}^{-1}$ ): 1629 (NO). CV: $E_{1 / 2}=-0.94 \mathrm{~V}$.

$\left[\mathbf{T p m}\left(\mathrm{PMe}_{3}\right) \mathrm{Mo}(\mathrm{NO}) \mathrm{Br} \mathrm{BF}_{4}\right.$ (26). To vigorously stirred suspension of [TpmMo(NO)Br $\left.{ }_{2}\right] \mathrm{BF}_{4}(320 \mathrm{mg}, 0.545 \mathrm{mmol})$ and zinc dust $(150 \mathrm{mg}, 2.29 \mathrm{mmol})$ in $\mathrm{CH}_{2} \mathrm{Cl}_{2}(6 \mathrm{~mL})$ was added trimethylphosphine $(1.5 \mathrm{~mL}$ of a $1 \mathrm{M}$ solution in $\mathrm{THF}, \sim 1.5$ $\mathrm{mmol})$. The dark red reaction mixture turned green. The reaction was checked by IR, and after 2.5 hours, the mixture was filtered through celite on a coarse frit and washed with $\mathrm{CH}_{2} \mathrm{Cl}_{2}(\sim 40 \mathrm{~mL})$ until the washings remained colorless, leaving behind a small amount of green material on top of the celite. The volume of the orange-red filtrate was reduced to $\sim 5 \mathrm{~mL}$ under vacuum, and ether was used to give an oily precipitate. The supernatant solution was decanted, and the semisolid residue was recrystallised from $\mathrm{CH}_{2} \mathrm{Cl}_{2}$ /ether, filtered, washed with ether, and dried under vacuum to give $\mathbf{2 6}$ (210 $\mathrm{mg}$, $0.360 \mathrm{mmol}, 66 \%)$ as a yellow powder. IR (HATR, $\left.\mathrm{CH}_{2} \mathrm{Cl}_{2}, \mathrm{~cm}^{-1}\right): 1640(\mathrm{NO}) . \mathrm{CV}: E_{1 / 2}$ $=-0.85 \mathrm{~V}$. Anal. calcd for $\mathrm{C}_{13} \mathrm{H}_{19} \mathrm{BBrF}_{4} \mathrm{MoN}_{7} \mathrm{OP}: \mathrm{C}, 26.78 ; \mathrm{H}, 3.29 ; \mathrm{N}, 16.82$. Found: C, 26.00; H, 4.06; N, 17.35.

$\left[\mathbf{T p m}\left(\mathbf{P}(\mathbf{O M e})_{3}\right) \mathbf{M o}(\mathbf{N O}) \mathbf{B r}_{3} \mathbf{B F}_{4}\right.$ (27). To a vigorously stirred suspension of [TpmMo(NO)Br $\left.{ }_{2}\right] \mathrm{BF}_{4}(425 \mathrm{mg}, 0.724 \mathrm{mmol})$ and zinc dust (300 $\left.\mathrm{mg}, 4.59 \mathrm{mmol}\right)$ in $\mathrm{CH}_{2} \mathrm{Cl}_{2}(12 \mathrm{~mL})$ was added trimethylphosphite $(1 \mathrm{~mL}, \sim 1.05 \mathrm{~g}, \sim 8.46 \mathrm{mmol})$. The dark red reaction mixture turned green. The reaction was monitored by IR, and after 2.5 hours, the mixture was filtered through celite on a coarse frit and washed with $\mathrm{CH}_{2} \mathrm{Cl}_{2}$ until the washings remained colorless $(\sim 60 \mathrm{~mL})$, leaving behind a small amount of green material. The volume of the brown filtrate was evaporated to $\sim 5 \mathrm{~mL}$ under vacuum. Ether was used to give a precipitate, which was filtered, washed with ether, and dried under vacuum to give 27 (225 - $250 \mathrm{mg}, 0.357-0.396 \mathrm{mmol}, 49-55 \%$ ) as a green 
powder. IR (HATR, $\mathrm{CH}_{2} \mathrm{Cl}_{2}, \mathrm{~cm}^{-1}$ ): $1651(\mathrm{NO}) . \mathrm{CV}: E_{1 / 2}=-0.53 \mathrm{~V}$. Anal. calcd for $\mathrm{C}_{13} \mathrm{H}_{19} \mathrm{BBrF}_{4} \mathrm{MoN}_{7} \mathrm{O}_{4} \mathrm{P}:$ C, 24.75; H, 3.04; N, 15.54. Found: C, 25.06; H, 3.24; N, 15.20.

Tp(DMAP)Mo(NO)(3,4- $\boldsymbol{\eta}^{2}$-naphthalene) (28). $\left.\mathrm{TpMo} \mathrm{NO}\right) \mathrm{Br}_{2}(5.95 \mathrm{~g}, 11.9$

$\mathrm{mmol}$ ) was dissolved in THF (125 mL), and to this solution was added zinc dust (1.56 $\mathrm{g}$, $23.9 \mathrm{mmol})$. After 7 minutes, the solution had turned green, and 4-

dimethylaminopyridine (DMAP, $1.52 \mathrm{~g}, 12.4 \mathrm{mmol}$ ) was added. After 80 minutes, sodium dispersion in wax $(30-35 \%, 1.68 \mathrm{~g})$ and naphthalene $(16.3 \mathrm{~g}, 127 \mathrm{mmol})$ were added, and the resulting mixture was stirred for 24 hours. The reaction mixture was diluted with ether $(100 \mathrm{~mL})$ and eluted through silica gel with ether. The eluent volume was reduced to $20 \mathrm{~mL}$ under vacuum, and pentane $(100 \mathrm{~mL})$ was added to precipitate an orange solid. The solid was collected and dried in vacuo to give 76 (2.91 g, $45.1 \%$ yield). This compound was observed as a 2:1 ratio of diastereomers, the major having the unbound naphthalene ring directed toward the DMAP ligand and the minor having the unbound naphthalene ring directed away from the DMAP ligand. ${ }^{1} \mathrm{H}$ NMR (acetone- $d_{6}$, $\delta)$ : (Major diastereomer) $8.10(\mathrm{~d}, J=1.26,1 \mathrm{H}, \mathrm{Tp} 3,5), 8.03(\mathrm{~d}, J=2.21,1 \mathrm{H}, \mathrm{Tp} 3,5)$, $7.92(\mathrm{~d}, J=2.33,1 \mathrm{H}, \mathrm{Tp} 3,5), 7.83(\mathrm{~d}, J=1.79,2 \mathrm{H}, 2 \times \mathrm{Tp} 3,5), 7.70(\mathrm{~d}, J=1.79,1 \mathrm{H}, \mathrm{Tp}$ 3,5), $7.83(\mathrm{~d}, J=1.79,2 \mathrm{H}, 2 \mathrm{x}$ Tp 3,5), $7.70(\mathrm{~d}, J=1.79,1 \mathrm{H}, \mathrm{Tp} 3,5), 7.24(\mathrm{~d}, J=6.42$, 1H, naphthalene 8), 7.08-6.67 (m, 5H, DMAP 2, 6, naphthalene 2, 6, 7), 6.59-6.46 (m, 3H, DMAP 3, 5, naphthalene 1), 6.40 (t, $J=2.17,1 \mathrm{H}, \mathrm{Tp} 4), 6.35$ (t, $J=2.16,1 \mathrm{H}, \mathrm{Tp} 4)$, $6.24(\mathrm{~d}, J=7.55,1 \mathrm{H}$, naphthalene 5), $6.06(\mathrm{t}, J=2.17,1 \mathrm{H}, \mathrm{Tp} 4), 3.80(\mathrm{~d}, J=8.44,1 \mathrm{H}$, naphthalene 4), $3.16(\mathrm{dd}, J=8.47,5.70,1 \mathrm{H}$, naphthalene 3$), 3.06\left(\mathrm{~s}, 6 \mathrm{H}, \mathrm{NMe}_{2}\right.$ ). (Minor diastereomer, select resonances) $8.05(\mathrm{~d}, J=2.27,1 \mathrm{H}, \mathrm{Tp} 3,5), 7.94(\mathrm{~d}, J=2.37,1 \mathrm{H}, \mathrm{Tp}$ 3,5), $7.54(\mathrm{~d}, J=1.80,1 \mathrm{H}, \mathrm{Tp} 3,5), 7.26(\mathrm{~d}, J=5.92,1 \mathrm{H}$, naphthalene 8), 7.08-6.67 (m, 4H, DMAP 2, 6, naphthalene 6, 7), 6.63 (dd, $J=8.96,5.44,1 \mathrm{H}$, naphthalene 2), 6.596.46 (m, 3H, DMAP 3, 5, naphthalene 1), 6.25 (t, $J=2.13,1 \mathrm{H}, \mathrm{Tp} 4), 6.10$ (t, 1H, Tp, overlapping with major diastereomer), $3.50(\mathrm{dd}, J=8.37,5.46,1 \mathrm{H}$, naphthalene 3$), 3.31$

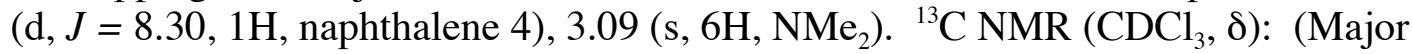
diastereomer) $153.4,150.2,142.3,141.9,140.2$, 136.1 , 135.6, 134.4, 133.5, 126.0, 125.8, 123.4, 122.9, 118.0 (DMAP 2, 4, 6, Tp 3,5, naphthalene 1, 2, 5, 6, 7, 8), 107.2, 105.6, 105.4 105.2 (DMAP 3, 5, Tp 4), 75.9 (naphthalene 4), 70.1 (naphthalene 3), $39.0\left(\mathrm{NMe}_{2}\right)$. (Minor diastereomer, some signals overlapping with major diastereomer): 153.7 (DMAP 2, 4, 6), 143.0, 141.2, 140.0, 136.0, 135.6, 132.4, 131.1,127.8, 127.7, 125.7, 117.7 (Tp 3,5, naphthalene 1, 2, 5, 6, 7, 8), 107.0 (br, DMAP 3, 5), 105.7, 105.1, 104.8 (Tp 4), 72.4 (naphthalene 3), 72.2 (naphthalene 4), 39.0 (overlapping with major diastereomer, $\mathrm{NMe}_{2}$ ). IR (HATR, $\left.\mathrm{cm}^{-1}\right): 1580$ (NO). CV: $E_{\mathrm{p}, \mathrm{a}}=-0.16 \mathrm{~V}, 0.85 \mathrm{~V}$. Due to extreme air sensitivity of this compound, purity was determined to be $>95 \%$ by $\mathrm{CV}$ and NMR data only.

$\mathbf{T p}\left(\mathbf{P}(\mathrm{OMe})_{3}\right) \mathbf{W}(\mathbf{N O})\left(\mathbf{3 , 4}-\boldsymbol{\eta}^{\mathbf{2}}\right.$-naphthalene) (29). $\mathrm{Tp}\left(\mathrm{P}(\mathrm{OMe})_{3}\right) \mathrm{W}(\mathrm{NO}) \mathrm{Br}(103.8$ $\mathrm{mg}, 0.1648 \mathrm{mmol}$ ) was dissolved in DME (12 mL), and excess naphthalene (300 $\mathrm{mg}, \sim 14$ eq) was added. To this mixture was added sodium amalgam $(1 \%, 9 \mathrm{~g})$, and the resulting mixture was stirred for 5 days and monitored by cyclic voltammetry. The reaction solution was decanted away from the $\mathrm{Na}$ amalgam and reduced to $5 \mathrm{~mL}$. After dilution with benzene $(30 \mathrm{~mL})$, this mixture was chomatographed on silica $(3 \mathrm{~cm})$ and eluted with 10:1 benzene:THF. A yellow fraction $(\sim 50 \mathrm{~mL})$ was collected, and its solvent was removed under reduced pressure. The resulting residue was dissolved in minimal THF and added to cold hexanes $(50 \mathrm{~mL})$ to produce a yellow precipitate which was collected 
on a medium-porosity frit and dried in vacuo to give $\mathbf{2 9}$ (42.6 mg, $0.0628 \mathrm{mmol}, 38 \%$ ) as a yellow powder. This compound was observed as a 5:1 ratio of diastereomers, the major having the unbound naphthalene ring directed away from the $\mathrm{P}(\mathrm{OMe})_{3}$ ligand and the minor having the unbound naphthalene ring directed toward the $\mathrm{P}(\mathrm{OMe})_{3}$ ligand. ${ }^{1} \mathrm{H}$ NMR (acetone- $\left.d_{6}, \delta\right): 8.28$ (d, $1 \mathrm{H}$, Tp minor), 7.98 (d, 1H, Tp major), $7.93(\mathrm{~d}, 2 \mathrm{H}, 2 \mathrm{x}$ Tp major), 7.90 (d, 1H, Tp major), 7.83 (d, 1H, Tp minor), 7.73 (d, 1H, Tp minor), 7.70 (d, $J=7.4,1 \mathrm{H}$, naphthalene unbound minor), 7.54 (d, $1 \mathrm{H}$, Tp major), 7.49 (dd, $J=6.2$, $3.1,1 \mathrm{H}$, naphthalene 6 or 7 minor), 7.11 (d, $J=7.4,1 \mathrm{H}$, naphthalene 8 major), 7.05 (dd, $J$ $=9.4,5.0,1 \mathrm{H}$, naphthalene 2 major), 7.00 ( $\mathrm{dd}, J=9.0,5.4,1 \mathrm{H}$, naphthalene 2 minor), 6.96 (buried, $1 \mathrm{H}$, naphthalene 6 or 7 minor), 6.95 (dd, $J=7.4,1.4,1 \mathrm{H}$, naphthalene 6 major), 6.92 (dd, $J=7.4,1.4,1 \mathrm{H}$, naphthalene 7 major), 6.91 (buried, $1 \mathrm{H}$, naphthalene 5 or 8 minor), 6.89 (d, $1 \mathrm{H}$, Tp major), $6.55(\mathrm{~d}, J=7.4,1 \mathrm{H}$, naphthalene 5 major), 6.39 (t, $1 \mathrm{H}$, Tp minor), 6.31 (t, 2H, $2 \times$ Tp major), 6.23 (t, 1H, Tp major), 6.21 (d, $J=9.0,1 \mathrm{H}$, naphthalene 1 minor), 6.11 (d, $J=9.4,1 \mathrm{H}$, naphthalene 1 major), 4.79 (dd, $J=11.8,9.5$, $1 \mathrm{H}$, naphthalene 4 minor), 4.35 (ddd, $J=23.5,9.4,5.0,1 \mathrm{H}$, naphthalene 3 major), 3.38 $\left(\mathrm{d}, J=10.7,9 \mathrm{H}, \mathrm{P}\left(\mathrm{OCH}_{3}\right)_{3}\right.$ major $), 3.02\left(\mathrm{~d}, J=11.0,9 \mathrm{H}, \mathrm{P}\left(\mathrm{OCH}_{3}\right)_{3}\right.$ minor $), 2.49(\mathrm{~d}, J=$ 9.4, $1 \mathrm{H}$, naphthalene 4 major), 2.41 (ddd, $J=9.5,5.4,1.8,1 \mathrm{H}$, naphthalene 3 minor). ${ }^{13} \mathrm{C}$ NMR (acetone- $d_{6}, \delta$ ): (major diastereomer, quaternary carbons not observed): 146.6 (s, Tp), 143.0 (s, Tp), 142.9 (s, Tp), 137.6 (s, Tp), 136.9 (s, Tp), 136.4 (s, Tp), 134.6 (s, naphthalene 2), 129.6 (s, naphthalene 5), 126.2 (s, naphthalene 8), 124.1 (s, naphthalene 6), 123.8 (s, naphthalene 7), 119.5 (s, naphthalene 1), 107.0 (s, Tp), 106.8 (s, Tp), 105.7 (s, Tp), 61.2 (s, naphthalene 4), 60.5 (d, $J=12.2$, naphthalene 3$), 51.8(\mathrm{~d}, J=4.6$, $\left.\mathrm{P}\left(\mathrm{OCH}_{3}\right)_{3}\right)$. (minor diastereomer, select resonance): $51.2\left(\mathrm{~d}, J=3.0, \mathrm{P}\left(\mathrm{OCH}_{3}\right)_{3}\right)$. IR $\left(\mathrm{HATR}, \mathrm{cm}^{-1}\right): 1585(\mathrm{NO}) . \mathrm{CV}: E_{\mathrm{p}, \mathrm{a}}=+0.23 \mathrm{~V} . \mathrm{MS}(\mathrm{ESI}): \mathrm{M}^{+}=680$. The structure of 29 was confirmed by single-crystal X-ray diffraction, and purity determined to be $>95 \%$ by $\mathrm{CV}$ and NMR data.

$\left.\mathbf{T p}\left(\mathbf{P}(\mathbf{O M e})_{3}\right) \mathbf{W}(\mathbf{N O})\left(\mathbf{2}, 3-\boldsymbol{\eta}^{2} \text {-furan) (30). Tp(P(OMe) }\right)_{3}\right) \mathrm{W}(\mathrm{NO}) \mathrm{Br}(106.0 \mathrm{mg}, 0.1683$ mmol) was dissolved in THF $(12 \mathrm{~mL})$, and furan $(1 \mathrm{~mL})$ was added. To this mixture was added $\mathrm{Na}$ amalgam $(1 \%, 9 \mathrm{~g})$, and the reaction was stirred for 3 days and monitored by cyclic voltammetry. The reaction solution was decanted away from the $\mathrm{Na}$ amalgam, and its solvent was removed under reduced pressure. The resulting residue was dissolved in THF ( $2 \mathrm{~mL})$, and this solution was diluted with $30 \mathrm{~mL}$ benzene and chomatographed on silica $(3 \mathrm{~cm})$ using 2:1 benzene:diethyl ether. A yellow-green fraction was collected $(\sim 50$ $\mathrm{mL})$, and its solvent was removed under reduced pressure until it froze. The solvent volume was doubled using hexanes $(25 \mathrm{~mL})$, and the solvent was then removed under reduced pressure. The resulting residue was dissolved in diethyl ether $(8 \mathrm{~mL})$ and transferred to a preweighed vial. The solvent was removed under reduced pressure, and the resulting material was dried in vacuo to give $\mathbf{3 0}$ (49.0 $\mathrm{mg}, 0.0792 \mathrm{mmol}, 47 \%)$ as a yellow residue. This compound was observed as a 10:1 ratio of diastereomers, the major having the furan oxygen directed toward the $\mathrm{P}(\mathrm{OMe})_{3}$ ligand and the minor having the furan oxygen directed away from the $\mathrm{P}(\mathrm{OMe})_{3}$ ligand. ${ }^{1} \mathrm{H}$ NMR (acetone- $d_{6}, \delta$ ): (major diastereomer only): 8.42 (br s, 1H, Tp), 8.06 (br s, 1H, Tp), 7.91 (br s, 1H, Tp), 7.88 (br s, 1H, Tp), 7.85 (br s, 1H, Tp), 7.28 (br s, 1H, Tp), 6.37 (br s, 1H, Tp), 6.36 (br s, 1H, Tp), 6.31 (br s, 1H, furan 5), 6.16 (br s, $1 \mathrm{H}, \mathrm{Tp}), 5.81$ (br s, $1 \mathrm{H}$, furan 4), 5.58 (t, $J=4.9$, $1 \mathrm{H}$, furan 2), 4.81 (ddd, $J=13.6,4.9,2.4,1 \mathrm{H}$, furan 3), $3.46\left(\mathrm{~d}, J=10.7,9 \mathrm{H}, \mathrm{P}(\mathrm{OMe})_{3}\right)$. ${ }^{13} \mathrm{C}$ NMR (acetone- $d_{6}, \delta$ ): (major diastereomer only): 146.5 (s, Tp), 143.1 (s, Tp), 142.5 
(s, Tp), 140.0 (s, furan 5), 137.4 (s, Tp), 136.2 (s, Tp), 135.7 (s, Tp), 111.2 (s, furan 4), 106.9 (s, Tp), 106.6 (s, Tp), 106.2 (s, Tp), 106.1 (s, furan 2), 56.6 (d, $J=15.6$, furan 3), $52.0\left(\mathrm{~d}, J=4.6, \mathrm{P}(\mathrm{OMe})_{3}\right)$. IR $\left(\mathrm{HATR}, \mathrm{cm}^{-1}\right): 2484(\mathrm{BH}), 1569(\mathrm{NO}) . \mathrm{CV}: E_{\mathrm{p}, \mathrm{a}}=+0.20$ $\mathrm{V}$.

\section{$\mathrm{Tp}\left(\mathrm{PMe}_{3}\right) \mathrm{W}(\mathrm{NO})\left(3,4-\eta^{2}\right.$-naphthalene) (31)}

$\mathrm{TpW}(\mathrm{NO})\left(\mathrm{PMe}_{3}\right) \mathrm{Br}(100.9 \mathrm{mg}, 0.1731 \mathrm{mmol})$ was added to THF $(10 \mathrm{~mL})$, then naphthalene $(1 \mathrm{~g})$ was added. $\mathrm{Next}, 1 \% \mathrm{Na} / \mathrm{Hg}$ was added to the reaction, and the reaction was stirred $2 \mathrm{~d}$. The reaction was then decanted away from $\mathrm{Na} / \mathrm{Hg}$ and the solvent of the reaction mixture was removed under reduced pressure and the residue was dissolved in benzene. The benzene solution was loaded onto a $\mathrm{SiO}_{2}$ plug $(3 \mathrm{~cm})$ and eluted with 1:1 benzene:diethyl ether. A yellow fraction was collected and the solvent was reduced to $\sim 10 \mathrm{~mL}$ under reduced pressure. Hexanes $(50 \mathrm{~mL})$ were added to give a yellow precipitate that was collected on a $15 \mathrm{~mL}$ medium porosity glass filter and dried in vacuo to give 5 (28.4 mg, 0.0450mmol, 26\%). IR (HATR glaze): $v=1569 \mathrm{~cm}^{-1}$. CV (DMA, TBAH, $100 \mathrm{mV} / \mathrm{s}$, vs. NHE): $\mathrm{E}_{\mathrm{p} . \mathrm{a}}=+0.11 \mathrm{~V}(\mathrm{I} / 0) .1 \mathrm{H}$ NMR (acetone-do, $\left.\delta\right): 8.00(1 \mathrm{H}$, $\mathrm{d}(J=2.1), \mathrm{Tp}), 7.94(1 \mathrm{H}, \mathrm{d}(J=2.4), \mathrm{Tp}), 7.89$ (1H, d $(J=2.1), \mathrm{Tp}), 7.86$ (1H, d(J=2.4), Tp), 7.50 (1H, d $(J=2.1), \mathrm{Tp}), 7.11(1 \mathrm{H}, \mathrm{d}(J=2.1), \mathrm{Tp}), 7.05$ (1H, dd $(J=7.3,1.2), \mathrm{C} 8), 6.93(1 \mathrm{H}$, $\operatorname{dt}(J=7.3,1.5), C 6), 6.86(2 \mathrm{H}, \mathrm{m}, \mathrm{C} 7+\mathrm{C} 2), 6.59(1 \mathrm{H}, \mathrm{d}(J=7.3), \mathrm{C} 5), 6.35(1 \mathrm{H}, \mathrm{t}(J=2.1)$, $\mathrm{Tp}), 6.31$ (1H, t $(J=2.3), \mathrm{Tp}), 6.19$ (1H, t $(J=2.3), \mathrm{Tp}), 6.05(1 \mathrm{H}, \mathrm{d}(J=9.2), \mathrm{C} 1), 3.85$ (1H, $\mathrm{m}, \mathrm{C} 3), 2.32$ (1H, d $(J=9.2), \mathrm{C} 4), 1.33\left(9 \mathrm{H}, \mathrm{d}(J=8.2)\right.$, PMe3). ${ }^{13} \mathrm{C}$ NMR (acetone- $\left.d_{6}, \delta\right)$ : 144.7 (s, Tp), 144.3 (s, quat), 143.0 (s, Tp), 141.6 (s, Tp), 137.5 (s, Tp), 137.0 (s, Tp), 136.7 (s, Tp), 133.0 (s, C7), 131.8 (s, quat), 129.1 (s, 5), 126.0 (s, 8), 124.0 (s, 6), 123.2 (s, 2), 118.9 (s, 1), 107.0 (br s, 2Tp), 105.4 (s, Tp), 60.7 (s, 4), 59.1 (br s, 3), 13.2 $\left(\mathrm{d}(J=22), \mathrm{PMe}_{3}\right)$.

\section{Substitution reactions of $\left.\mathrm{TpmM}(\mathrm{NO})(\mathrm{CO})_{2}\right] \mathrm{BF}_{4}$ complexes.}

$\left[\mathbf{T p m}\left(\mathbf{P P h}_{3}\right) \mathbf{M o}(\mathbf{N O})(\mathbf{C O})\right] \mathbf{B F}_{4}$. [TpmMo(NO)(CO) $\left.)_{2}\right] \mathrm{BF}_{4}(800 \mathrm{mg}, 1.66 \mathrm{mmol})$ and triphenylphosphine $(1.00 \mathrm{~g}, 3.810 \mathrm{mmol})$ were refluxed in DMF $(20 \mathrm{~mL})$ for 1-2 hours with monitoring by IR. The resulting solution was poured into water $(60 \mathrm{~mL})$. The resulting mixture was stirred briefly, and precipitate was collected in a medium-porosity fritted-glass funnel, washed with water $(2 \times 20 \mathrm{~mL})$, acetone $(3 \times 5 \mathrm{~mL})$, and diethyl ether ( 3 x $5 \mathrm{~mL}$ ), and vacuum-dried overnight to give 3 (710-745 mg, 0.99-1.04 mmol, 60$63 \%$ ) as a pink powder. ${ }^{1} \mathrm{H} \mathrm{NMR}\left(\mathrm{DMF}-d_{7}, \delta\right): 10.14\left(\mathrm{br} \mathrm{s}, 1 \mathrm{H}, \mathrm{HC}(\mathrm{pz})_{3}\right), 8.79$ (br s, $1 \mathrm{H}), 8.72(\mathrm{br} \mathrm{s}, 2 \mathrm{H}), 8.36(\mathrm{~d}, J=1.8,1 \mathrm{H}), 7.23-7.61(\mathrm{~m}, 15 \mathrm{H}), 7.10(\mathrm{~d}, J=2.1,1 \mathrm{H}) 7.04$ $(\mathrm{d}, J=2.1,1 \mathrm{H}), 6.74$ (br s, $1 \mathrm{H}), 6.54$ (br s, $1 \mathrm{H}), 6.38$ (br s, $1 \mathrm{H}) .{ }^{13} \mathrm{C} \mathrm{NMR}\left(\mathrm{DMF}-d_{7}, \delta\right)$ : 244.0 (d, $J=8, \mathrm{CO}), 147.4$ (s), 146.6 (s), 146.5 (s), 136.9 (s), 136.8 (s), 136.1 (s), 133.8 $(\mathrm{d}, J=11), 133.6\left(\mathrm{~d}, J=39, i-\mathrm{PC}_{6} \mathrm{H}_{5}\right), 131.3\left(\mathrm{~d}, J=2, p-\mathrm{PC}_{6} \mathrm{H}_{5}\right), 129.6(\mathrm{~d}, J=9), 109.2$ (s), 108.9 (s), 108.4 (s), 77.1 (s, HC(pz) $\left.)_{3}\right) .{ }^{31} \mathrm{P} \mathrm{NMR} \mathrm{(DMF-} d_{7}, \delta$ ): 54.7 (s). IR (HATR, $\left.\mathrm{DMF}, \mathrm{cm}^{-1}\right): 1911(\mathrm{CO}), 1627(\mathrm{NO}) . \mathrm{CV}: E_{\mathrm{p}, \mathrm{c}}=-1.92 \mathrm{~V}, E_{\mathrm{p}, \mathrm{a}}=+0.95 \mathrm{~V}$. Anal. calcd for $\mathrm{C}_{29} \mathrm{H}_{25} \mathrm{BF}_{4} \mathrm{MoN}_{7} \mathrm{O}_{2} \mathrm{P}: \mathrm{C}, 48.56 ; \mathrm{H}, 3.51 ; \mathrm{N}, 13.67$. Found: C, 48.56; H, 3.53; N, 13.92.

$\left[\mathbf{T p m}\left(\mathbf{P M e}_{3}\right) \mathbf{M o}(\mathbf{N O})(\mathbf{C O})\right] \mathbf{B F}_{4}$. Trimethylphosphine $(3 \mathrm{~mL}$ of a $1 \mathrm{M}$ in THF solution) was added to $\left[\mathrm{TpmMo}(\mathrm{NO})(\mathrm{CO})_{2}\right] \mathrm{BF}_{4}(800 \mathrm{mg}, 1.66 \mathrm{mmol})$ in THF $(20 \mathrm{~mL})$, upon which the yellow suspension turned green. The resulting mixture was refluxed for 2 hours, with completion of the reaction being checked by IR, to give a dark solution. This solution was filtered through silica gel $(0.5 \mathrm{~cm})$ and celite $(0.5 \mathrm{~cm})$ on a mediumporosity frit. The filtration medium was washed with THF/acetone (4:1 v:v, 4 x $25 \mathrm{~mL})$, and the solvent of the resulting dark red solution was evaporated under vacuum. The 
remaining solid was washed with acetone ( $4 \times 2 \mathrm{~mL})$ and diethyl ether $(2 \times 25 \mathrm{~mL})$ and vacuum dried overnight to give product (490-510 $\mathrm{mg}, 0.923-0.960 \mathrm{mmol}, 56-58 \%)$ as an orange-red powder. ${ }^{1} \mathrm{H} \mathrm{NMR}\left(\mathrm{CD}_{3} \mathrm{CN}, \delta\right)$ : $9.05\left(\mathrm{~s}, 1 \mathrm{H}, \mathrm{HC}(\mathrm{pz})_{3}\right), 8.36(\mathrm{~d}, J=2.4,1 \mathrm{H})$, $8.31(\mathrm{~d}, J=2.4,1 \mathrm{H}), 8.27(\mathrm{~d}, J=2.4,1 \mathrm{H}), 8.09(\mathrm{~d}, J=2.1,1 \mathrm{H}), 8.04(\mathrm{~d}, J=2.1,1 \mathrm{H})$, $7.91(\mathrm{~d}, J=2.1,1 \mathrm{H}), 6.60(\mathrm{dd}, J=2.4,2.1,1 \mathrm{H}, \mathrm{pz} 4), 6.52(\mathrm{dd}, J=2.4,2.1,1 \mathrm{H}, \mathrm{pz} 4)$, $6.51(\mathrm{dd}, J=2.4,2.1,1 \mathrm{H}, \mathrm{pz} 4), 1.47\left(\mathrm{~d}, J=8.4,9 \mathrm{H}, \mathrm{P}\left(\mathrm{CH}_{3}\right)_{3}\right) .{ }^{13} \mathrm{C} \mathrm{NMR}\left(\mathrm{CD}_{3} \mathrm{CN}, \delta\right)$ : 147.7 (s), 147.1 (s), 146.9 (s), 135.9 (s), 135.8 (s), 135.2 (s), 109.3 (s), 109.2 (s), 108.9 (s), $77.0\left(\mathrm{~s}, \mathrm{HC}(\mathrm{pz})_{3}\right), 16.7\left(\mathrm{~d}, J=27, \mathrm{P}\left(\mathrm{CH}_{3}\right)_{3}\right)$, carbonyl carbon not observed. ${ }^{31} \mathrm{P}$ NMR $\left(\mathrm{CD}_{3} \mathrm{CN}, \delta\right): 5.0(\mathrm{~s})$. IR (HATR, THF, $\left.\mathrm{cm}^{-1}\right): 1907(\mathrm{CO}), 1631(\mathrm{NO}) . \mathrm{CV}: E_{\mathrm{p}, \mathrm{c}}=-1.95$ $\mathrm{V}, E_{\mathrm{p}, \mathrm{a}}=+0.80 \mathrm{~V}$. Anal. calcd for $\mathrm{C}_{14} \mathrm{H}_{19} \mathrm{BF}_{4} \mathrm{MoN}_{7} \mathrm{O}_{2} \mathrm{P}: \mathrm{C}, 31.66 ; \mathrm{H}, 3.61 ; \mathrm{N}, 18.46$. Found: C, 31.85; H, 3.87; N, 18.87 .

$\left[\mathbf{T p m}\left(\mathbf{P M e}_{3}\right) \mathbf{W}(\mathbf{N O})(\mathbf{C O})\right] \mathbf{B F}_{4}$. A suspension of $\left[\mathrm{TpmW}(\mathrm{NO})(\mathrm{CO})_{2}\right] \mathrm{BF}_{4}(1.00 \mathrm{~g}$, $1.75 \mathrm{mmol})$ and trimethylphosphine $(600 \mu \mathrm{L}, 441 \mathrm{mg}, 5.80 \mathrm{mmol})$ in butanone $(20 \mathrm{~mL})$ was refluxed for 16 hours, during which time the color of the mixture changed from orange to red, gas evolution was observed and completion of the reaction was checked by IR. The solvent volume was evaporated to $\sim 5 \mathrm{~mL}$ under vacuum, and the mixture was poured into diethyl ether $(60 \mathrm{~mL})$. The resulting mixture was stirred for 30 minutes, and the supernatant solvent was decanted. The remaining red residue was taken up in acetone $(5 \mathrm{~mL})$, and diethyl ether $(30 \mathrm{ml})$ produced a red precipitate. The solid was collected in a fine-fritted sintered-glass funnel, washed with diethyl ether $(2 \times 10 \mathrm{~mL})$ and dried under vacuum to give the product (790-860 mg, $1.28-1.39 \mathrm{mmol}, 73-79 \%)$ as a red powder. ${ }^{1} \mathrm{H}$ NMR $\left(\mathrm{CD}_{3} \mathrm{CN}, \delta\right): 9.11$ (br s, $\left.1 \mathrm{H}, \mathrm{HC}(\mathrm{Pz})_{3}\right), 8.41$ (br s, $\left.1 \mathrm{H}\right), 8.35$ (br s, $\left.1 \mathrm{H}\right), 8.30$ (br s, $1 \mathrm{H}), 8.14(\mathrm{~d}, J=1.8,1 \mathrm{H}), 8.10(\mathrm{~d}, J=1.8,1 \mathrm{H}) 7.94(\mathrm{~d}, J=1.8,1 \mathrm{H}), 6.62(\mathrm{br} \mathrm{s}, 1 \mathrm{H}), 6.52$ (br s, $2 \mathrm{H}), 1.58\left(\mathrm{~d}, J=9,9 \mathrm{H}, \mathrm{P}\left(\mathrm{CH}_{3}\right)_{3}\right) .{ }^{13} \mathrm{C} \mathrm{NMR}\left(\mathrm{CD}_{3} \mathrm{CN}, \delta\right): 246.0(\mathrm{~d}, J=9, \mathrm{CO})$, 148.1 (s), 147.3 (s), 147.2 (s), 136.3 (s), 136.0 (s), 135.3 (s), 109.7 (s), 109.7 (s), 109.3 (s), $77.6\left(\mathrm{~s}, \mathrm{HC}(\mathrm{pz})_{3}\right), 17.3\left(\mathrm{~d}, J=31, \mathrm{P}\left(\mathrm{CH}_{3}\right)_{3}\right) .{ }^{31} \mathrm{P} \mathrm{NMR}\left(\mathrm{CD}_{3} \mathrm{CN}, \delta\right):-13.1\left(\mathrm{~s},{ }^{1} J(\mathrm{~W}, \mathrm{P})\right.$ = 387). IR (HATR, butanone, $\left.\mathrm{cm}^{-1}\right): 1886(\mathrm{CO}), 1603(\mathrm{NO}) . \mathrm{CV}: E_{\mathrm{p}, \mathrm{c}}=-1.85 \mathrm{~V}, E_{1 / 2}=$ $+0.67 \mathrm{~V}$.

$\left[\mathbf{T p m}\left(\mathbf{P}(\mathbf{O M e})_{3}\right) \mathbf{M o}(\mathbf{N O})(\mathbf{C O}) \mathbf{B F}_{4}\right.$. Trimethylyphosphite $(\sim 2 \mathrm{~mL}, \sim 2.1 \mathrm{~g}, 16.9$ $\mathrm{mmol})$ was added to $\left[\mathrm{TpmMo}(\mathrm{NO})(\mathrm{CO})_{2}\right] \mathrm{BF}_{4}(800 \mathrm{mg}, 1.66 \mathrm{mmol})$ in THF (20 ml), upon which the yellow suspension turned green. The resulting mixture was refluxed for 12 hours, with completion of the reaction being checked by IR, to give a dark solution. It was filtered through silica gel $(0.5 \mathrm{~cm})$ and celite $(0.5 \mathrm{~cm})$ on a medium porosity frit and the filtration medium was washed with THF/acetone $(4: 1 \mathrm{v}: \mathrm{v}, 4$ x $25 \mathrm{~mL})$. The solvent of the resulting dark solution was evaporated under vacuum, giving a dark oil that was washed with diethyl ether $(20 \mathrm{~mL})$ to remove excess trimethylyphosphite. The remaining solid was washed with acetone (4 x $2 \mathrm{~mL})$ and diethyl ether $(2 \times 25 \mathrm{~mL})$ and vacuum dried overnight to give product (560-580 $\mathrm{mg}, 0.967-1.00 \mathrm{mmol}, 58-60 \%)$ as an orangered powder. ${ }^{1} \mathrm{H} \mathrm{NMR}\left(\mathrm{CD}_{3} \mathrm{CN}, \delta\right): 9.06\left(\mathrm{~s}, 1 \mathrm{H}, \mathrm{HC}(\mathrm{pz})_{3}\right), 8.36(\mathrm{~d}, J=2.4,1 \mathrm{H}), 8.33(\mathrm{~d}$, $J=2.4,1 \mathrm{H}), 8.30(\mathrm{~d}, J=2.4,1 \mathrm{H}), 8.12(\mathrm{~d}, J=2.1,1 \mathrm{H}), 8.09(\mathrm{~d}, J=2.1,1 \mathrm{H}), 7.93(\mathrm{~d}, J=$ 2.1, 1H), 6.59 (dd, $J=2.4,2.1,1 \mathrm{H}$; pz 4), 6.56 (dd, $J=2.4,2.1$, pz 4), 6.49 (dd, $J$ 2.4, 2.1, pz 4), 3.60 (d, $\left.J=10.8,9 \mathrm{H}, \mathrm{P}\left(\mathrm{OCH}_{3}\right)_{3}\right) .{ }^{13} \mathrm{C} \mathrm{NMR}\left(\mathrm{CD}_{3} \mathrm{CN}, \delta\right): 238.9$ (d, $\left.J=15, \mathrm{CO}\right)$, 147.9 (s), 147.8 (s), 147.6 (d, $J=2), 136.1$ (s), 135.9 (s), 135.6 (d, $J=2), 109.4$ (d, $J=2)$, 109.3 (s), 108.8 (s), 77.0 (s, $\left.\mathrm{HC}(\mathrm{pz})_{3}\right), 52.7$ (d, $\left.J=5, \mathrm{P}\left(\mathrm{OCH}_{3}\right)_{3}\right) .{ }^{31} \mathrm{P}$ NMR $\left(\mathrm{CD}_{3} \mathrm{CN}, \delta\right)$ : 169.7 (s). IR (HATR, THF, $\mathrm{cm}^{-1}$ ): $1929(\mathrm{CO}), 1641$ (NO). CV: $E_{\mathrm{p}, \mathrm{c}}=-1.88 \mathrm{~V}, E_{\mathrm{p}, \mathrm{a}}=$ 
+0.99 V. Anal. calcd for $\mathrm{C}_{14} \mathrm{H}_{19} \mathrm{BF}_{4} \mathrm{MoN}_{7} \mathrm{O}_{5} \mathrm{P}: \mathrm{C}, 29.04 ; \mathrm{H}, 3.31 ; \mathrm{N}, 16.93$. Found: $\mathrm{C}$, $29.57 ; \mathrm{H}, 3.21 ; \mathrm{N}, 16.41$.

[Tpm(P(OMe $\left.)_{3}\right) \mathbf{W}(\mathbf{N O})(\mathbf{C O}) \mathbf{B F}_{4}$. Trimethylyphosphite $(4.00 \mathrm{~mL}, 4.20 \mathrm{~g}, 33.8$ $\mathrm{mmol})$ was added to $\left[\mathrm{TpmW}(\mathrm{NO})(\mathrm{CO})_{2}\right] \mathrm{BF}_{4}(1.00 \mathrm{~g}, 1.75 \mathrm{mmol})$ in propionitrile $(20$ $\mathrm{mL}$ ). The resulting orange suspension was refluxed for 16 hours, with completion of the reaction being checked by IR. The volume of the resulting red reaction solution was reduced by evaporation under vacuum to $\sim 5 \mathrm{~mL}$. The remaining mixture was poured into diethyl ether $(60 \mathrm{~mL})$, giving a red-orange oily precipitate. The cloudy yellow supernatant solution was decanted, and the remaining residue was treated with acetone (2 $\mathrm{mL})$ and reprecipitated with diethyl ether $(30 \mathrm{~mL})$. The precipitate was collected in a fine-fritted glass funnel, washed with diethyl ether $(2 \times 10 \mathrm{~mL})$, and vacuum dried for 2 hours to give the product (760-820 mg, $1.14-1.23 \mathrm{mmol}, 65-70 \%)$ as an orange powder. ${ }^{1} \mathrm{H}$ NMR $\left(\mathrm{CD}_{3} \mathrm{CN}, \delta\right): 9.10\left(\mathrm{~s}, 1 \mathrm{H}, \mathrm{HC}(\mathrm{pz})_{3}\right), 8.38(\mathrm{~d}, J=2.4,1 \mathrm{H}), 8.34(\mathrm{~d}, J=2.4,1 \mathrm{H})$, $8.33(\mathrm{~d}, J=2.4,1 \mathrm{H}), 8.19(\mathrm{~d}, J=2.4,1 \mathrm{H}), 8.16(\mathrm{~d}, J=2.4,1 \mathrm{H}), 7.97(\mathrm{~d}, J=2.4,1 \mathrm{H})$, $6.61(\mathrm{t}, J=2.4,1 \mathrm{H}, \mathrm{pz} 4), 6.58(\mathrm{t}, J=2.4,1 \mathrm{H}, \mathrm{pz} 4), 6.50(\mathrm{t}, J=2.4 \mathrm{~Hz}, 1 \mathrm{H}, \mathrm{pz} 4), 3.62$ $\left(\mathrm{d}, J=11.1,9 \mathrm{H}, \mathrm{P}\left(\mathrm{OCH}_{3}\right)_{3}\right) .{ }^{13} \mathrm{C} \mathrm{NMR}\left(\mathrm{CD}_{3} \mathrm{CN}, \delta\right): 238.1(\mathrm{~d}, J=6, \mathrm{CO}), 148.2$ (s), 148.1 (s), 148.0 (s), 136.4 (s), 136.1 (s), 135.7 (s), 109.8 (s), 109.6 (s), 109.2 (s), 77.6 (s, $\left.\mathrm{HC}(\mathrm{pz})_{3}\right), 53.1\left(\mathrm{~d}, J=5, \mathrm{P}\left(\mathrm{OCH}_{3}\right)_{3}\right) .{ }^{31} \mathrm{P} \mathrm{NMR}\left(\mathrm{CD}_{3} \mathrm{CN}, \delta\right): 152.5\left(\mathrm{~s},{ }^{1} J(\mathrm{~W}, \mathrm{P})=611 \mathrm{~Hz}\right)$. IR (HATR, EtCN, cm ${ }^{-1}$ ): $1905(\mathrm{CO}), 1621(\mathrm{NO}) . \mathrm{CV}: E_{\mathrm{p}, \mathrm{c}}=-1.87 \mathrm{~V}, E_{1 / 2}=+0.87 \mathrm{~V}$. Anal. calcd for $\mathrm{C}_{14} \mathrm{H}_{19} \mathrm{BF}_{4} \mathrm{~N}_{7} \mathrm{O}_{5} \mathrm{PW}$ : C, 25.21; H, 2.87; N, 1470. Found: C, 25.02; H, $2.93 ; \mathrm{N}, 14.42$.

(1) McCleverty, J. A.; Seddon, D.; Bailey, N. A.; Walker, N. W. J. J. C. S. Dalton 1976, 898-908.

(2) Deane, M. E.; Lalor, F. J. J. Organomet. Chem. 1974, 67, C19.

(3) Graham, P.; Meiere, S. H.; Sabat, M.; Harman, W. D. Organometallics 2003, 22, 4364-4366.

(4) Mocella, C. J.; Delafuente, D. A.; Keane, J. M.; Warner, G. R.; Friedman, L. A.; Sabat, M.; Harman, W. D. Organometallics 2004, 23, 3772-3779. 


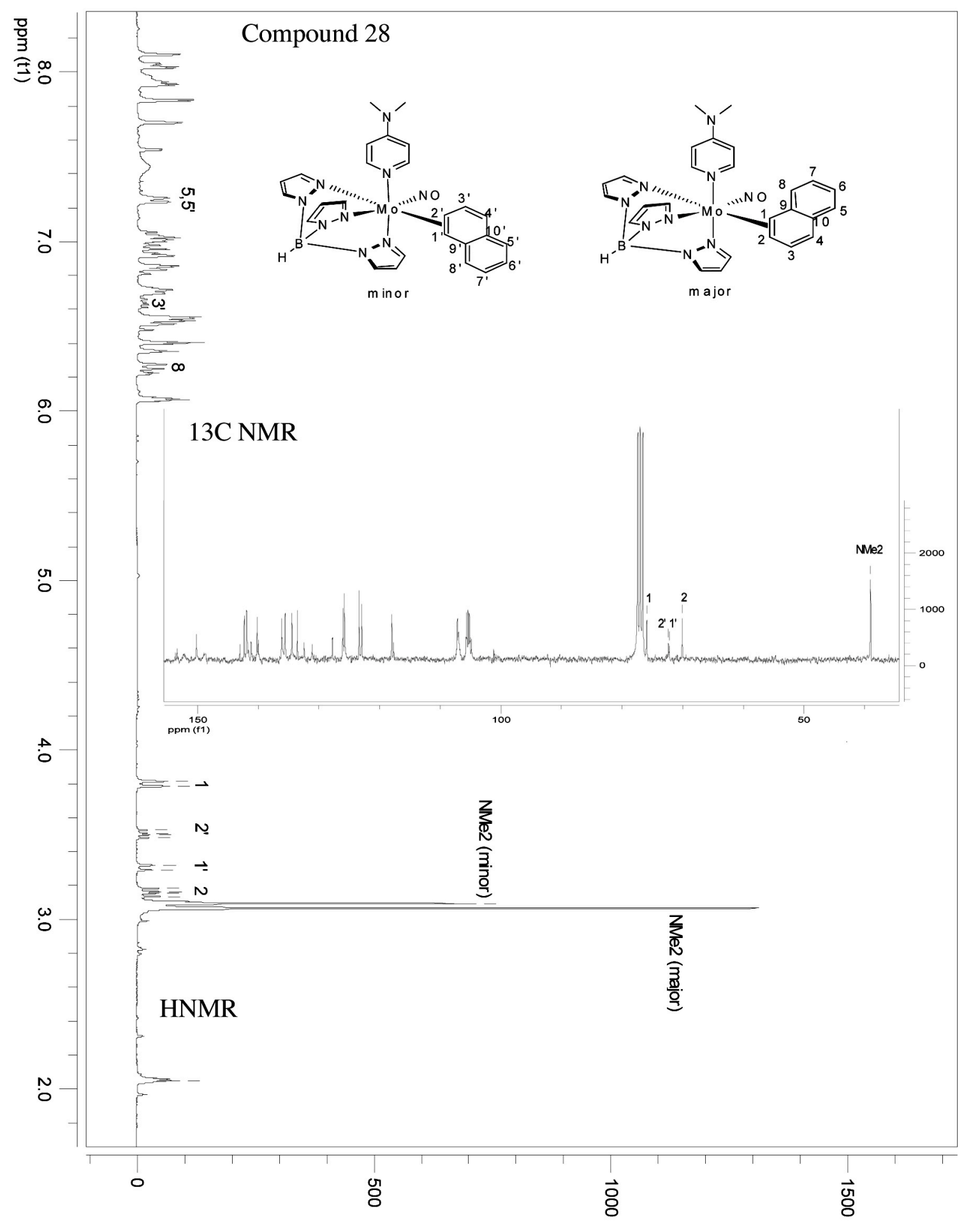




\section{Compound 29}

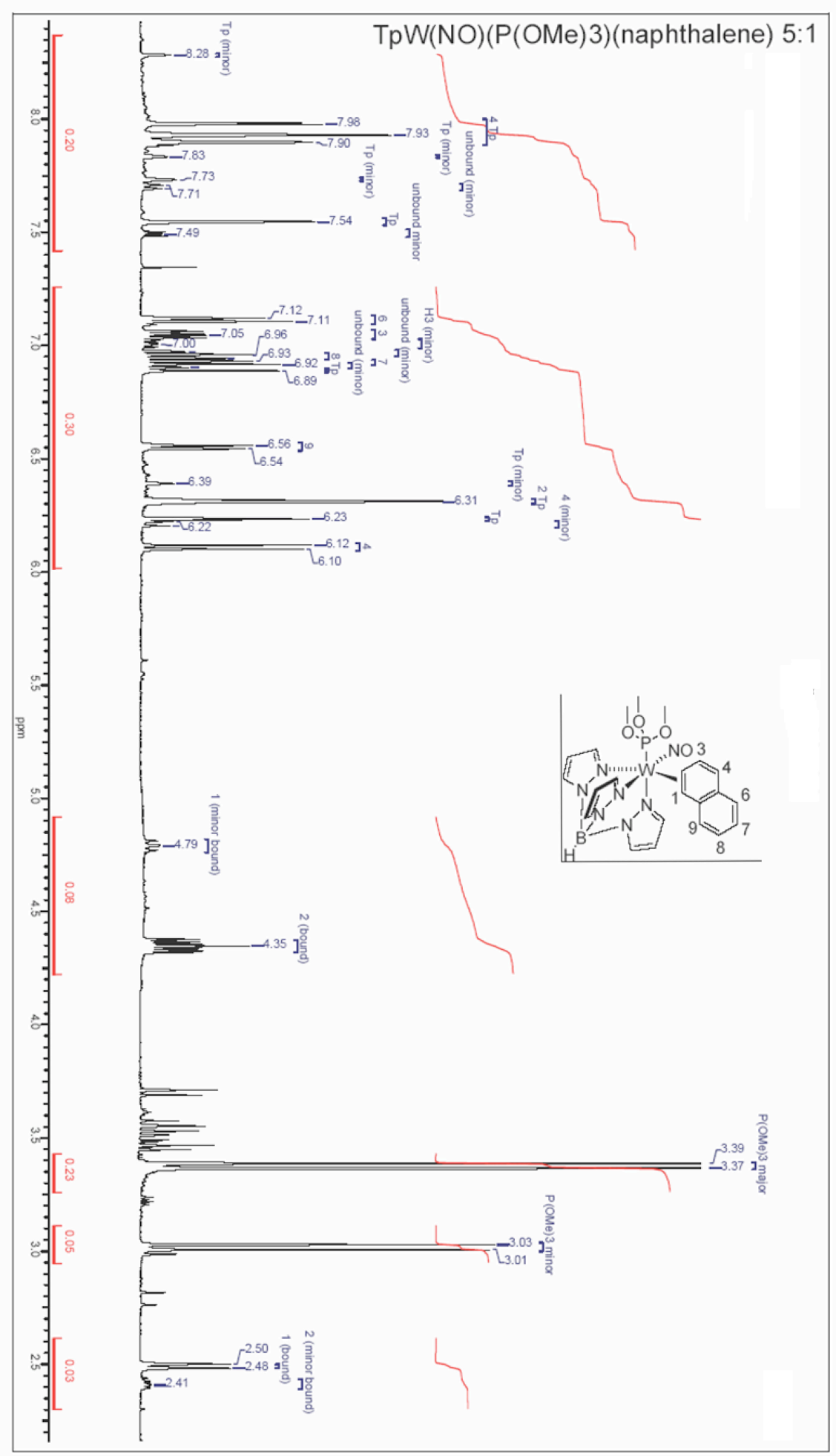

径 


\section{Compound 30 :}

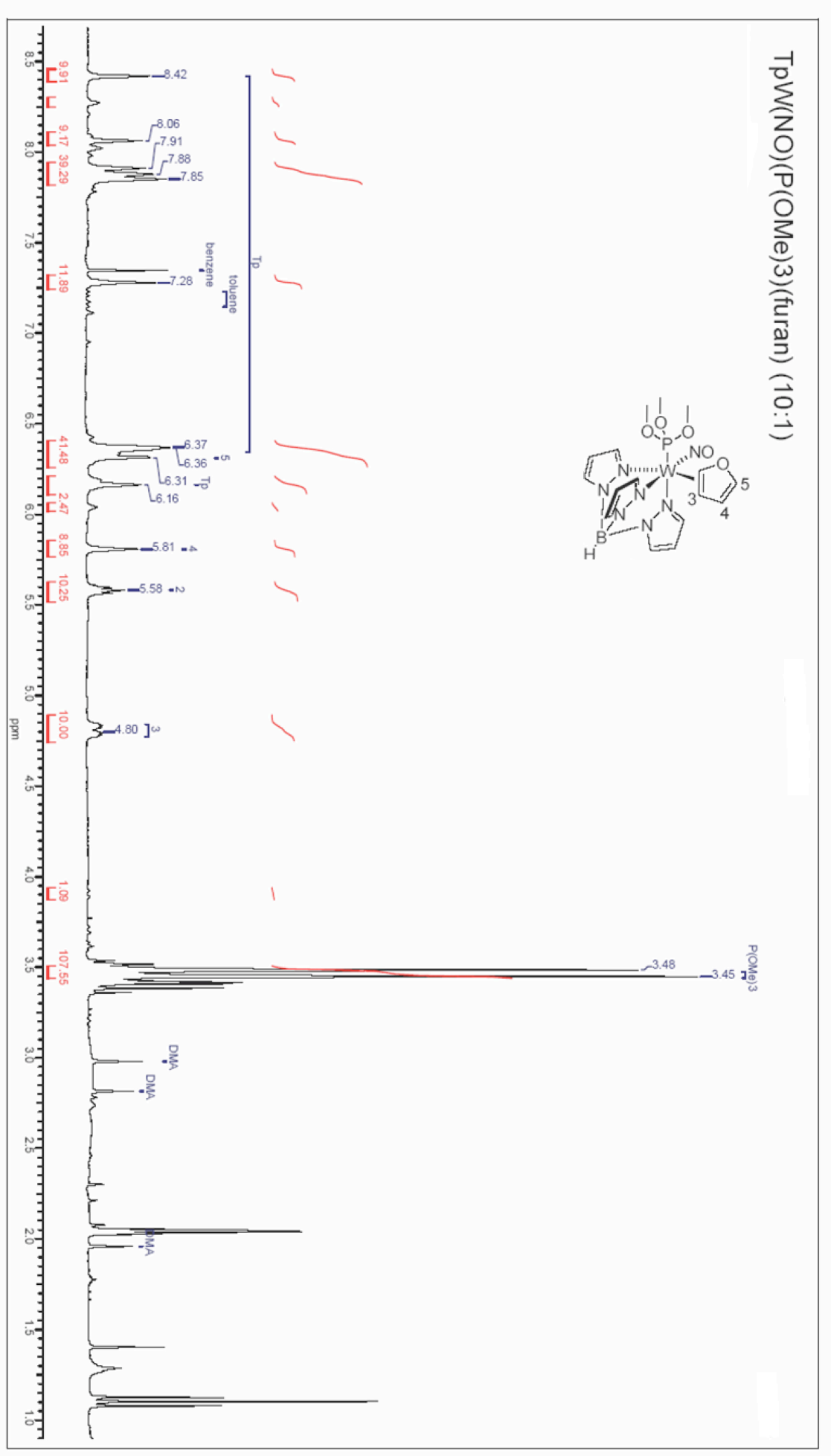




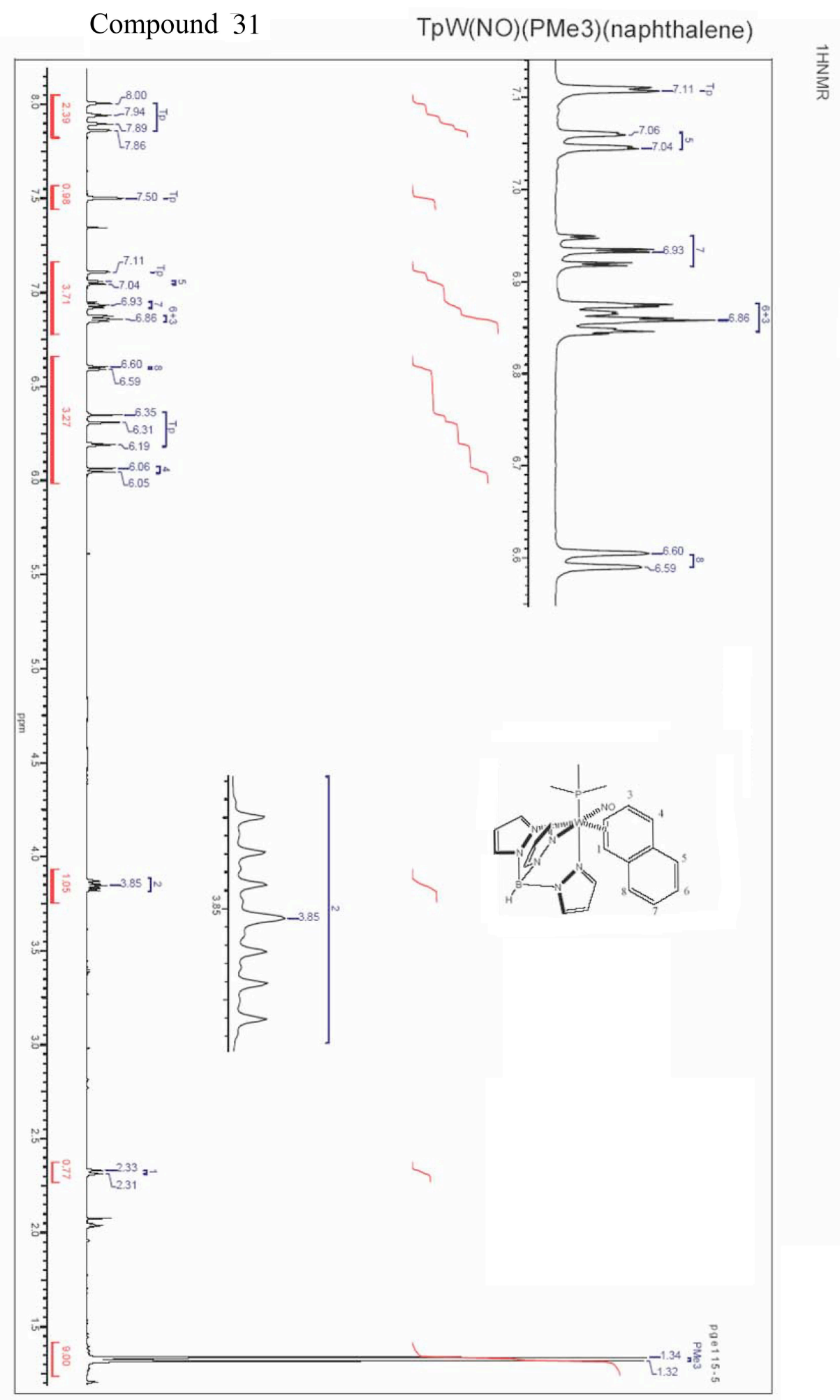

